\title{
KEMASAN SEKUNDER THREE IN ONE TERHADAP MINAT BELI KONSUMEN PADA MADU SUMBAWA
}

\author{
Irwandi $^{\star}$, Yolli Eka Putri, S.Si.,M.M², Mikharatunnisa, S.Si.,M.,Si ${ }^{3}$ \\ $1,2^{\star} 3^{\star}$ Fakultas Teknologi Pertanian Universitas Teknologi Sumbawa \\ *Corresponding Author email: ${ }^{1}$ irwandi@uts.ac.id , ${ }^{2}$ yolly.ekaputri@uts.ac.id, ${ }^{3}$ mikhratunnisa@uts.ac.id
}

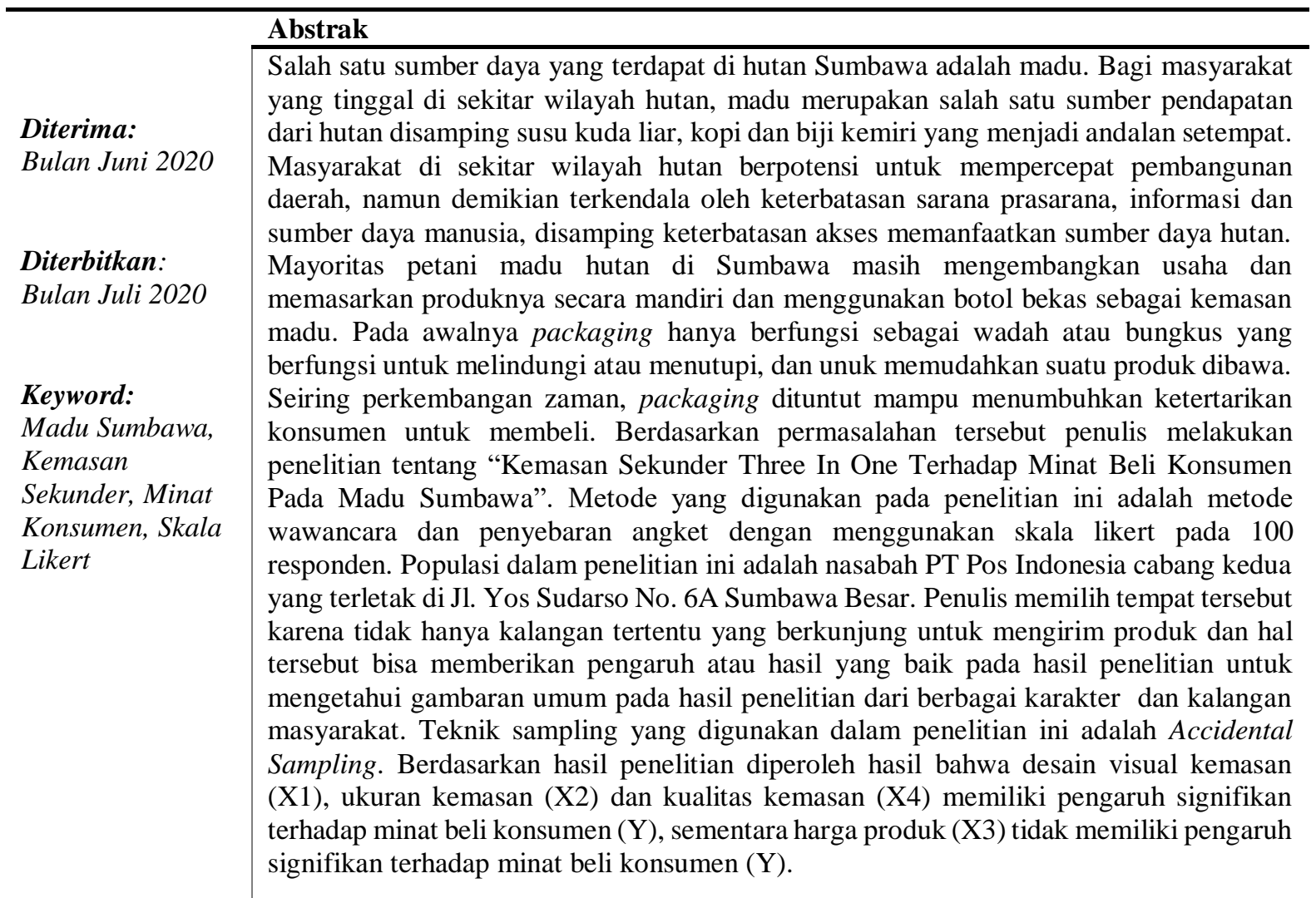

\section{PENDAHULUAN}

Sumbawa adalah pulau yang kaya akan sumber daya alam. Hutan adalah salah satu kekayaan alam yang dimiliki oleh Sumbawa. Luas hutan Kabupaten Sumbawa mencapai 516.242 ha yang terdiri dari hutan lindung (243.765,53 ha), hutan produksi terbatas $(177.669,51$ ha), hutan produksi tetap $(58.379,30$ ha $)$, taman buru (22.537,90 ha), cagar alam $(2.165,25 \mathrm{ha})$, wisata alam (5.725 ha) dan taman laut (6.000 ha) (Yamin, 2017). Sebanyak $45,21 \%$ merupakan hutan lindung yang berfungsi sebagai perlindungan ekosistem. Sumber daya yang terdapat di hutan merupakan sumber daya yang penting bagi kehidupan mahluk di bumi. Salah satu sumber daya yang terdapat di hutan Sumbawa adalah madu. Bagi masyarakat yang tinggal disekitar wilayah hutan, madu merupakan salah satu sumber pendapatan dari hutan disamping produk susu kuda liar, kopi, serta biji kemiri yang menjadi andalan setempat. Hasil survei Dinas Kehutanan Sumbawa yang dilakukan. Pada tahun 2008 menyatakan bahwa potensi madu hutan sumbawa diperkirakan mencapai 125 ton/tahun, sedangkan produksinya mencapai 40 ton/tahun. Apabila didayagunakan, potensi tersebut dapat mengurangi beban belanja pemerintah melalui adanya aktivitas perputaran modal yang dibutuhkan dalam pembangunan perekonomian daerah (Retno, dkk., 2012).

Sebenarnya masyarakat di sekitar wilayah hutan berpotensi untuk mempercepat pembangunan daerah, namun demikian terkendala oleh keterbatasan sarana prasarana, informasi, dan sumber daya manusia, disamping keterbatasan akses memanfaatkan sumber daya hutan. Selain itu 
mayoritas petani madu hutan di Sumbawa masih mengembangkan usaha dan memasarkan produknya secara mandiri dan menggunakan botol bekas sebagai kemasan madu. Dengan adanya permasalahan-permasalahan tersebut menyebabkan hasil hutan seperti madu Sumbawa susah untuk dipasarkan dan susah untuk mendapatkan kepercayaan dari konsumen baik di tingkat lokal, nasional, maupun internasional (Retno, dkk., 2012).

Konsumen biasanya membeli suatu produk karena alasan kebutuhan. Namun ada alasan atau faktor-faktor lain yang turut serta mempengaruhi konsumen dalam pengambilan keputusan, seperti dalam hal visual, bentuk dan ukuran, teknologi, label informasi yang terdapat pada kemasan suatu produk. Oleh karena itu perusahaan-perusahaan mulai membuat suatu inovasi terhadap produknya yaitu dengan cara membuat kemasan dengan desain dan model yang bervariasi sehingga membuat konsumen tertarik untuk membelinya.

Berdasarkan latar belakang di atas penulis ingin melakukan penelitian tentang "Kemasan Sekunder Three In One Terhadap Minat Beli Konsumen Pada Madu Sumbawa”. Diharapkan dengan adanya penelitian ini dapat menjadi salah satu cara menjaga kelestarian budaya nasional berbasis kearifan lokal produk madu hutan Sumbawa, serta dapat meningkatkan minat beli konsumen, nilai jual dan daya saing produk madu Sumbawa dengan produk-produk madu lainnya yang sudah dikenal dan beredar ditingkat nasional bahkan internasional. Selain itu diharapkan dengan adanya inovasi kemasan sekunder nanti dapat mengurangi biaya pengiriman ketika madu dikirim keluar daerah karena tidak perlu dipacking kayu lagi.

\section{LANDASAN TEORI}

\section{Daya Tarik Kemasan}

Kunci utama untuk membuat sebuah desain kemasan yang baik adalah kemasan tersebut harus simple (sederhana), fungsional, dan menciptakan respons emosional positif yang secara tidak langsung "berkata", "Belilah saya". Kemasan harus dapat menarik perhatian secara visual, emosional, dan rasional. Sebuah desain kemasan yang bagus memberikan sebuah nilai tambah terhadap produk yang dikemasnya. Menurut penelitian, dari seluruh kegiatan penginderaan manusia, $80 \%$ adalah penginderaan melalui penglihatan atau kasatmata (visual). Karena itulah, unsur-unsur grafis dari kemasan antara lain: warna, bentuk, merek, ilustrasi, huruf, dan tata letak merupakan unsur visual yang mempunyai peran terbesar dalam proses penyampaian pesan secara kasatmata (visual communication). Agar berhasil, maka penampilan sebuah kemasan harus mempunyai daya tarik. Daya tarik pada kemasan dapat digolongkan menjadi dua, yaitu daya tarik visual (estetika) dan daya tarik praktis (fungsional) (Muhammad, 2010).

Daya tarik visual mengacu pada penampilan kemasan yang mencakup unsur-unsur grafis yang telah disebutkan di atas. Semua unsur grafis tersebut dikombinasikan untuk menciptakan suatu kesan untuk memberikan daya tarik visual secara optimal. Daya tarik visual sendiri berhubungan dengan faktor emosi dan psikologis yang terletak pada bawah sadar manusia. Sebuah desain yang baik harus mampu mempengaruhi konsumen untuk memberikan respon positif tanpa disadarinya. Sering terjadi konsumen membeli suatu produk yang tidak lebih baik dari produk lainnya walaupun harganya lebih mahal. Dalam hal ini dapat dipastikan bahwa terdapat daya tarik tertentu yang mempengaruhi konsumen secara psikologis tanpa disadarinya. Misalnya produk-produk sabun mandi yang pada umumnya memiliki komposisi yang tidak jauh berbeda. Tetapi produk sabun mandi yang dapat menampilkan kelembutan yang divisualkan dengan baik pada desain kemasannya, di antaranya menggunakan warna-warna lembut (pastel) dan merek dengan font Script atau Italic (miring) dan memberikan kesan lembut dan anggun akan lebih banyak dipilih oleh konsumen. Visualisasi yang ditampilkan memberikan efek psikologis bahwa konsumen akan merasakan kulitnya lebih lembut setelah menggunakan sabun mandi tersebut (Oktaviani, 2016).

Daya tarik praktis (fungsional) merupakan efektivitas dan efisiensi suatu kemasan yang ditujukan kepada konsumen maupun distributor. Misalnya, untuk kemudahan penyimpanan atau pemajangan produk. Beberapa daya tarik praktis lainnya yang perlu dipertimbangkan antara lain:

(1) Dapat melindungi produk.

(2) Mudah dibuka atau ditutup kembali.

(3) Porsi yang sesuai untuk produk.

(4) Dapat digunakan kembali (reusable).

(5) Mudah dibawa, dijinjing atau dipegang.

(6) Memudahkan pemakai untuk menghabiskan isinya dan mengisi kembali dengan jenis produk yang dapat diisi ulang (refill).

Selain mempertimbangkan daya tarik atau dapat juga disebut dengan nilai estetika kemasan, ada beberapa hal yang harus dipenuhi dalam perancangan desain kemasan, antara lain: pertama, kemasan harus menonjol. Kalau kemasan tidak atau kurang menonjol maka kemasan akan kehilangan 
fungsinya, karena suatu produk harus bersaing dengan berpuluh-puluh produk lainnya dalam kategori yang sama di tempat penjualan (Anjelia, 2008). Salah satu cara adalah dengan penggunaan warna yang cermat, karena konsumen melihat warna jauh lebih cepat daripada melihat bentuk atau rupa, dan warnalah yang pertama kali terlihat bila produk berada di tempat penjualan. Warna yang terang akan lebih terlihat dari jarak jauh, karena memiliki daya tarik dan dampak yang lebih besar. Kedua, konten (isi) Kemasan harus dapat memberikan informasi tentang isi kemasan dan apa yang terkandung dalam produk. Misalnya, pada kemasan produk-produk makanan biasanya dicantumkan kandungan gizi produk tersebut dan berapa kalori yang dihasilkan setelah konsumen mengkonsumsi produk tersebut (Rahman, 2008)

\section{Hipotesis Penelitian}

Berdasarkan teori-teori yang digunakan sebagai landasan dalam penelitian mengenai pengaruh kemasan sekunder three in one terhadap minat beli konsumen pada madu sumbawa, maka dapat dirumuskan beberapa hipotesis penelitian yang berkaitan dengan variabel-variabel yang diteliti, yaitu visual kemasan, ukuran kemasan, harga produk, dan kualitas kemasan sebagai berikut: HO : Tidak ada pengaruh signifikan antara visual kemasan, ukuran kemasan, harga produk dan kualitas kemasan terhadap minat beli konsumen.

H1 : Visual kemasan berpengaruh positif terhadap minat beli konsumen.

H2 : Ukuran kemasan berpengaruh positif terhadap minat beli konsumen.

H3 : Harga berpengaruh positif terhadap minat beli konsumen.

H4 : Kualitas kemasan berpengaruh positif terhadap minat beli konsumen.

H5 : Visual kemasan, ukuran kemasan, harga produk dan kualitas kemasan berpengaruh secara bersamaan terhadap minat beli konsumen.

\section{METODE PENELITIAN}

\section{Waktu dan Tempat Penelitian}

Penelitian atau penyebaran kuesioner dimulai dari hari sabtu 1 April 2017 sampai dengan hari rabu 31 Mei 2017 yang bertempat di PT Pos Indonesia Jl. Yos Sudarso No. 6A Sumbawa Besar.

\section{Jenis dan Sumber Data}

Pada penelitian ini menggunakan dua jenis data, yaitu data primer dan data sekunder. Data primer diperoleh melalui pembagian kuesioner atau angket, dan wawancara mengenai kemasan madu Sumbawa produk yang tidak menggunakan kemasan sekunder dengan produk madu yang menggunakan kemasan sekunder yang merupakan inovasi dari peneliti. Pertanyaan dalam kuesioner dibuat dengan menggunakan skala Likert dengan ketentuan jawaban sangat tidak setuju diberi nilai $=$ 1 , untuk jawaban tidak setuju diberi nilai $=2$, untuk jawaban setuju diberi nilai $=3$, dan untuk jawaban sangat setuju diberi nilai $=4$. Pada penelitian ini responden diharuskan memilih salah satu dari keempat alternatif jawaban yang tersedia. Nilai yang diperoleh akan dijumlahkan dan jumlah tersebut menjadi nilai total. Nilai total inilah yang akan ditafsirkan sebagai posisi responden dalam skala Likert. Sedangkan data sekunder yang digunakan adalah data jumlah nasabah pada PT Pos Indonesia cabang kedua yang terletak di Jl. Yos Sudarso No. 6A Sumbawa Besar dan data mengenai madu sumbawa yang diperoleh dari studi kepustakaan.

\section{Metode Pengambilan Sampel}

Populasi dalam penelitian ini adalah nasabah PT Pos Indonesia Indonesia cabang kedua yang terletak di Jl. Yos Sudarso No. 6A Sumbawa Besar, rata-rata pengunjung PT Pos Indonesia cabang kedua yang terletak di Jl. Yos Sudarso No. 6A Sumbawa Besar per bulan adalah 3.000 orang. Dalam penelitian ini penentuan jumlah sampel menggunakan rumus slovin. Rumus slovin dijelaskan sebagai berikut (Rahman, 2008):

$$
\mathrm{n}=\frac{\mathrm{N}}{1+\mathrm{N}(\mathrm{e})^{2}}
$$

Keterangan:

$\mathrm{n}=$ Jumlah Sampel

$\mathrm{N}=$ Jumlah Populasi

e = Batas Toleransi Kesalahan (10\%)

Sehingga jumlah sampel dalam penelitian ini adalah sebagai berikut:

$$
n=\frac{3000}{1+3000(0,1)^{2}}=96,77
$$

Berdasarkan hasil perhitungan diatas, maka jumlah sampel yang digunakan adalah 96,77 responden. Agar penelitian ini menjadi lebih epektif maka jumlah sampel diambil menjadi 100 responden. Teknik pengambilan sampel dalam penelitian ini dilakukan dengan teknik Accidental Sampling. Accidental Sampling merupakan teknik pengambilan sampel berdasarkan kebetulan yaitu siapa saja yang secara kebetulan bertemu dengan peneliti bisa dijadikan sampel bila dipandang orang yang kebetulan ditemui itu cocok sebagai sumber data (Mohammad, 2012).

\section{Variabel dan Indikator - Indikator}

Pada penelitian ini menggunakan dua variabel yaitu variabel bebas $(\mathrm{X})$ dan variabel terikat $(\mathrm{Y})$. Variabel bebas $(\mathrm{X})$ dalam penelitian ini yaitu desain kemasan, dalam kuesioner variabel bebas dibagi menjadi 4 dimensi, yaitu: Desain Visual $\left(\mathrm{X}_{1}\right)$, Kualitas $\left(\mathrm{X}_{2}\right)$, Ukuran $\left(\mathrm{X}_{3}\right)$, dan Harga $\left(\mathrm{X}_{4}\right)$. 
Sedangkan yang menjadi variabel terikat (Y) adalah minat beli konsumen.

\section{Pengolahan Data dan Analisis Data}

Untuk menguji kualitas data pada penelitian ini menggunakan dua uji yaitu uji validitas dan uji reliabilitas. Uji validitas adalah alat untuk menguji apakah tiap-tiap pertanyaan benar telah mengungkapkan faktor atau indikator yang ingin diteliti. Uji validitas pada penelitian dilakukan penghitungan dengan menggunakan bantuan program SPSS 16.0.

Sedangkan uji reliabilitas merupakan suatu teknik yang digunakan untuk mengukur tingkat keandalan dan kestabilan pertanyaan. Pengujian reliabilitas menggunakan teknik reliability analysist alpha yang dibantu dengan hasil penghitungan Software SPSS 16.0. Dalam penelitian ini digunakan analisis deskriptif dan analisis regresi linear berganda. Analisis deskriptif digunakan untuk mengidentifikasi karakteristik responden, dan mendeskripsikan jawaban responden. Sedangkan analisis regresi linear berganda digunakan untuk mengetahui variabel bebas (X) yang dominan mempengaruhi minat beli konsumen variabel (Y).

\section{HASIL DAN PEMBAHASAN}

\section{Hasil Uji Validitas dan Reliabilitas}

Untuk mengetahui koefisien korelasi validitas pada setiap item kuisioner penelitian dilakukan penghitungan dengan menggunakan bantuan program SPSS 16.0. Hasil pengujian koefisien validitas adalah sebagai berikut:

Tabel 1 Hasil Uji Validitas Terhadap Minat

Beli Konsumen

\begin{tabular}{|l|l|l|l|}
\hline No & $\begin{array}{l}\text { Koefisien } \\
\text { Korelasi }\end{array}$ & $\begin{array}{l}\text { Kritik } \\
\text { Product } \\
\text { Moment }\end{array}$ & $\begin{array}{l}\text { Hasil } \\
\text { Pengujian }\end{array}$ \\
\hline 1 & 0,769 & 0514 & VALID \\
\hline 2 & 0,700 & 0,514 & VALID \\
\hline 3 & 0,752 & 0,514 & VALID \\
\hline 4 & 0,828 & 0,514 & VALID \\
\hline 5 & 0,904 & 0,514 & VALID \\
\hline 6 & 0,776 & 0,514 & VALID \\
\hline 7 & 0,829 & 0,514 & VALID \\
\hline 8 & 0,701 & 0,514 & VALID \\
\hline 9 & 0,726 & 0,514 & VALID \\
\hline 10 & 0,654 & 0,514 & VALID \\
\hline 11 & 0,755 & 0,514 & VALID \\
\hline 12 & 0,632 & 0,514 & VALID \\
\hline 13 & 0,719 & 0,514 & VALID \\
\hline 14 & 0,786 & 0,514 & VALID \\
\hline 15 & 0,844 & 0,514 & VALID \\
\hline
\end{tabular}

Hasil koefisien validitas dari 15 pernyataan kuesioner penelitian memenuhi kriteria valid karena hasil pengukuran koefisien korelasi > dari r tabel.

Untuk pengujian reliabilitas menggunakan teknik reliability analysist alpha yang dibantu juga dengan hasil penghitungan Software SPSS 16.0.

Tabel 2 Hasil Uji Reliabilitas Variabel X

\begin{tabular}{|l|l|}
\hline Cronbach's Alpha & N of Items \\
\hline 0.834 & 11 \\
\hline
\end{tabular}

Tabel 3 Hasil Uji Reliabilitas Variabel Y

\begin{tabular}{|l|l|}
\hline Cronbach's Alpha & N of Items \\
\hline 0.720 & 4 \\
\hline
\end{tabular}

Berdasarkan Tabel uji Reliabilitas Variable X dan Y diperoleh Alpha Cronbach untuk variabel bebas (X) sebesar 0,834 dan untuk variabel terikat (Y) sebesar 0,720, maka setiap pernyataan pada kuesioner reliable karena Alpha Cronbach > 0,60.

\section{Analisis Deskriptif}

\section{Analisis Deskriptif Karakteristik Responden}

\section{A. Umur Responden}

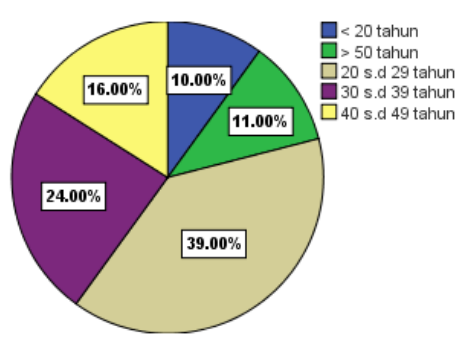

Gambar 1

\section{B. Jenis Kelamin}

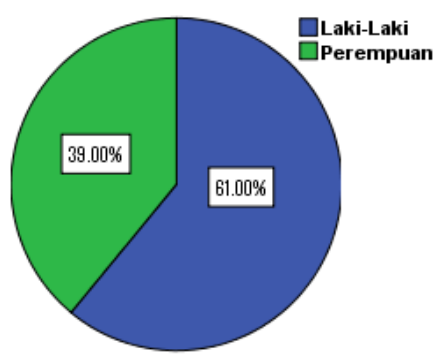

Gambar 2 


\section{Profesi}

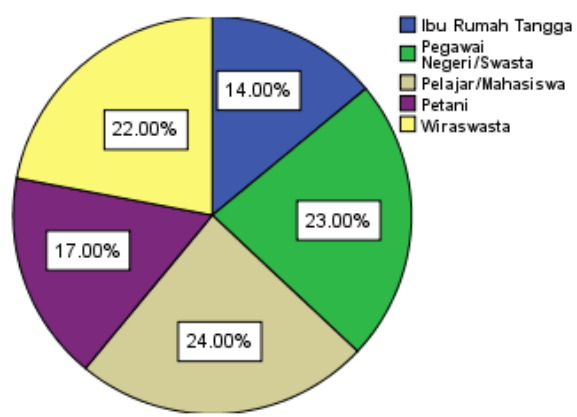

Gambar 3

\section{Analisis Regresi Berganda}

Analisis regresi berganda digunakan untuk mengetahui pengaruh variabel bebas $(\mathrm{X})$ terhadap variabel terikat (Y) (Mohammad, 2012). Persamaan regresi linear berganda dicari dengan menggunakan bantuan Software SPSS 16.0. Adapun persamaan regresi berganda dari penelitian ini adalah sebagai berikut:

$\begin{array}{ll}\mathrm{Y}=\mathrm{a}+\mathrm{b} 1 \mathrm{X} 1+\mathrm{b} 2 \mathrm{X} 2+\mathrm{b} 3 \mathrm{X} 3+\mathrm{b} 4 \mathrm{X} 4+\mathrm{e} \\ \text { Dimana: } \\ \mathrm{Y} & : \text { Minat Konsumen } \\ \mathrm{a} & \text { : Konstanta } \\ \mathrm{b} 1, \mathrm{~b} 2 \text { dan b3 } & \text { : Koefisien Regresi } \\ \mathrm{X} 1 & \text { : Visual Kemasan } \\ \mathrm{X} 2 & \text { : Ukuran Kemasan } \\ \mathrm{X} 3 & \text { : Harga Produk } \\ \mathrm{X} 4 & : \text { Kualitas Kemasan } \\ \mathrm{e} & : \text { error }\end{array}$

Tabel 4 Analisis Regresi Masing-Masing Variabel X Terhadap Y

\begin{tabular}{|c|c|c|c|c|c|}
\hline \multirow[t]{2}{*}{ Model } & \multicolumn{2}{|c|}{$\begin{array}{l}\text { Unstandardi } \\
\text { zed } \\
\text { Coefficients }\end{array}$} & \multirow{2}{*}{$\begin{array}{c}\text { Standard } \\
\text { ized } \\
\text { Model } \\
\text { Coefficie } \\
\text { nts } \\
\text { Beta }\end{array}$} & \multirow[t]{2}{*}{$\mathbf{T}$} & \multirow[t]{2}{*}{ Sig. } \\
\hline & B & $\begin{array}{c}\text { Std. } \\
\text { Erro } \\
\text { r } \\
\end{array}$ & & & \\
\hline 1 & 0,10 & 0,249 & & 0,41 & 0,68 \\
\hline $\begin{array}{c}\text { Consta } \\
\text { nt }\end{array}$ & 3 & & & 3 & 0 \\
\hline $\mathrm{X}_{1}$ & $\begin{array}{c}0,77 \\
5\end{array}$ & 0,235 & 0,258 & $\begin{array}{c}3,30 \\
4\end{array}$ & $\begin{array}{c}0,00 \\
1\end{array}$ \\
\hline $\mathrm{X}_{2}$ & $\begin{array}{c}0,32 \\
6\end{array}$ & 0,149 & 0,198 & $\begin{array}{c}2,18 \\
9\end{array}$ & $\begin{array}{c}0,03 \\
1\end{array}$ \\
\hline$X_{3}$ & $\begin{array}{c}0,07 \\
6\end{array}$ & 0,065 & 0,092 & $\begin{array}{c}1,16 \\
4\end{array}$ & $\begin{array}{c}0,24 \\
7\end{array}$ \\
\hline $\mathrm{X}_{4}$ & $\begin{array}{c}0,48 \\
8\end{array}$ & 0,073 & 0,480 & $\begin{array}{c}6,64 \\
3\end{array}$ & $\begin{array}{c}0,00 \\
0\end{array}$ \\
\hline
\end{tabular}

Sehingga model persamaan regresi yang diperoleh adalah:

$\mathrm{Y}=0.103+0.775 \mathrm{X}_{1}+0.326 \mathrm{X}_{2}+0.076 \mathrm{X}_{3}+0.488 \mathrm{X}_{4}$

Interpretasi dari model regresi yang diperoleh adalah:

1. Variabel visual kemasan $\left(\mathrm{X}_{1}\right)$ memberikan pengaruh positif terhadap minat beli konsumen. Setiap perubahan atau peningkatan variabel ini sebanyak 1 poin akan meningkatkan minat beli konsumen sebanyak 0.775 .

2. Variabel ukuran kemasan $\left(\mathrm{X}_{2}\right)$ memberikan pengaruh positif terhadap minat beli konsumen. Setiap perubahan atau Peningkatan variabel ini sebanyak 1 poin akan meningkatkan minat beli konsumen sebanyak 0.326 .

3. Variabel harga kemasan $\left(\mathrm{X}_{3}\right)$ memberikan pengaruh positif terhadap minat beli konsumen. Setiap perubahan atau Peningkatan variabel ini sebanyak 1 poin akan meningkatkan minat beli konsumen sebanyak 0.076 .

4. Variabel kualitas kemasan $\left(\mathrm{X}_{4}\right)$ memberikan pengaruh positif terhadap minat beli konsumen. Setiap perubahan atau Peningkatan variabel ini sebanyak 1 poin akan meningkatkan minat beli konsumen sebanyak 0.488 .

Untuk mengetahui apakah hipotesis yang diajukan dalam penelitian ini diterima atau ditolak maka akan dilakukan pengujian hipotesis dengan menggunakan uji $\mathrm{t}$ dan uji $\mathrm{F}$.

\section{Uji F (Secara Keseluruhan)}

Analisis regresi berganda dengan menggunakan uji $\mathrm{F}$ (Fisher) bertujuan untuk mengetahui pengaruh semua variabel yang meliputi, visual kemasan, ukuran kemasan, harga produk dan kualitas kemasan terhadap minat beli konsumen pada madu sumbawa secara bersamaan. Apabila nilai signifikansi lebih kecil dari 0,05 ( sig<0,05) maka model regresi signifikan secara statistik. Nilai

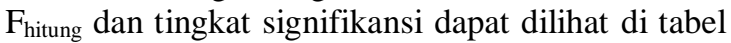
statistik berikut ini:

Tabel 5 ANOVA Uji Signifikansi

\begin{tabular}{|l|l|c|c|c|c|}
\hline Model & $\begin{array}{c}\text { Sum of } \\
\text { Squares }\end{array}$ & Df & $\begin{array}{c}\text { Mean } \\
\text { Square }\end{array}$ & F & Sig. \\
\hline 1 & 9,617 & 4 & 2,404 & 50,3 & 0,000 \\
Regression & & & & 04 & \\
\hline Residual & 4,540 & 95 & 0,048 & & \\
\hline Total & 14,157 & 99 & & & \\
\hline
\end{tabular}

Berdasarkan Tabel tersebut diperoleh nilai signifikansi 0,000 dimana nilai signifikansi lebih kecil dari $0,05(0,000<0,05)$, maka H0 ditolak dan hipotesis yang menyatakan bahwa terdapat pengaruh signifikan antara visual kemasan, ukuran kemasan, harga produk dan kualitas kemasan secara 
bersama-sama terhadap minat beli konsumen terbukti atau benar.

\section{Uji t (Secara Parsial)}

Uji $t$ merupakan pengujian untuk menunjukkan pengaruh secara individual variabel bebas (X) terhadap variabel terikat (Y) atau pengujian hipotesis 1 sampai hipotesis 4 (H1-H4). Apabila nilai thitung lebih besar dari ttabel dan nilai signifikansi lebih kecil dari 0,05 ( $\mathrm{sig}<0,05)$, maka dapat disimpulkan bahwa variabel bebas secara parsial berpengaruh signifikan terhadap variabel terikat. Penjelasan hasil uji t untuk masing-masing variabel bebas adalah sebagai berikut:

a. Visual Kemasan $\left(\mathrm{X}_{1}\right)$

Hasil statistik uji t untuk variabel visual kemasan diketahui nilai signifikansi sebesar 0,001 dimana signifikansi lebih kecil dari 0,05 $(0,001<0,05)$, maka $(\mathrm{H} 1)$ hipotesis yang menyatakan bahwa visual kemasan berpengaruh terhadap minat beli konsumen terbukti atau benar.

b. Ukuran Kemasan $\left(\mathrm{X}_{2}\right)$

Hasil statistik uji t untuk variabel ukuran kemasan diketahui bahwa nilai signifikansi sebesar 0,031 dimana signifikansi lebih kecil dari 0,05 $(0,031<0,05)$, maka $(\mathrm{H} 2)$ hipotesis yang menyatakan bahwa ukuran kemasan berpengaruh terhadap minat beli konsumen terbukti atau benar.

c. Harga Produk $\left(\mathrm{X}_{3}\right)$

Hasil statistik uji t untuk variabel harga produk diketahui bahwa nilai signifikansi sebesar 0,247 dimana signifikansi lebih besar dari $0,05(0,247>0,05)$, maka hipotesis (H3) yang menyatakan bahwa harga produk berpengaruh terhadap minat beli konsumen tidak terbukti atau tidak benar.

d. Kualitas Kemasan $\left(\mathrm{X}_{4}\right)$

Hasil statistik uji t untuk variabel kualitas kemasan diketahui bahwa nilai signifikansi sebesar 0,000 dimana signifikansi lebih kecil dari $0,05(0,00>0,05)$, maka hipotesis (H4) yang menyatakan bahwa kualitas kemasan berpengaruh terhadap minat beli konsumen terbukti atau benar adanya (Ni, 2013).

\section{Koefisien Determinasi}

Koefisien determinasi merupakan suatu alat untuk mengukur besarnya persentase pengaruh variabel bebas terhadap variabel terikat. Besarnya koefisien determinasi berkisar antara angka 0 sampai dengan 1, besar koefisien determinasi mendekati angka 1, maka semakin besar pengaruh variabel independen terhadap variabel dependen. Untuk tingkat hubungan atau pengaruh variabel bebas terhadap variabel terikat dapat dilihat pada tabel berikut (Mohammad, 2012):

Tabel Pedoman Interprestasi Koefisien Korelasi

\begin{tabular}{|l|l|l|}
\hline No & Interval Koefesien & Tingkat Hubungan \\
\hline 1 & $0,000-0,199$ & Sangat Lemah \\
\hline 2 & $0,200-0,399$ & Lemah \\
\hline 3 & $0,400-0,599$ & Cukup Kuat \\
\hline 4 & $0,600-0,799$ & Kuat \\
\hline 5 & $0,800-1,000$ & Sangat Kuat \\
\hline \multicolumn{3}{|c|}{ Sedangkan untuk koefisien determinasi }
\end{tabular}
dapat dilihat pada hasil yang didapatkan dari bantuan Software SPSS pada tabel berikut ini :

Tabel 6 Tabel Koefisien Determinasi

\begin{tabular}{|l|l|l|l|l|}
\hline Model & $\mathbf{R}$ & $\begin{array}{l}\text { R } \\
\text { Square }\end{array}$ & $\begin{array}{l}\text { Adjusted } \\
\text { R } \\
\text { Square }\end{array}$ & $\begin{array}{l}\text { Std. } \\
\text { Error of } \\
\text { the } \\
\text { Estimate }\end{array}$ \\
\hline 1 & 0,824 & 0,679 & 0,666 & 0,219 \\
\hline
\end{tabular}

Berdasarkan Tabel tersebut didapatkan nilai $\mathrm{R}^{2}$ sebesar 0,679 . Hal ini menjelaskan bahwa minat konsumen dipengaruhi oleh visual kemasan, ukuran kemasan, harga produk dan kualitas kemasan sebesar $67,9 \%$ sedangkan sisanya sebesar $32,1 \%$ dipengaruhi oleh faktor lain yang tidak diteliti dalam penelitian ini. Nilai 0,679 yang diperoleh juga menjelaskan bahwa hubungan atau pengaruh yang terjadi antara variabel bebas (visual kemasan, ukuran kemasan, harga produk dan kualitas kemasan) dengan variabel terikat (minat konsumen) berada dalam kategori kuat $(0,600-0,799)$ (Rani, 2016).

\section{PENUTUP \\ Kesimpulan}

Berdasarkan hasil penelitian maka dapat ditarik kesimpulan bahwa desain visual kemasan memiliki pengaruh signifikan terhadap minat beli konsumen, ukuran kemasan tidak memiliki pengaruh yang signifikan terhadap minat beli konsumen pada madu Sumbawa, harga produk tidak memiliki tidak memiliki pengaruh yang signifikan terhadap minat beli konsumen pada madu Sumbawa, kualitas kemasan memiliki pengaruh signifikan terhadap minat beli konsumen pada madu Sumbawa, dan visual kemasan, ukuran kemasan, harga produk dan kualitas kemasan secara bersama-sama memiliki pengaruh signifikan terhadap minat beli konsumen pada madu Sumbawa. Jadi aspek atau unsur utama yang harus diperhatikan pada kemasan sekunder tersebut adalah desain visual dan kualitas kemasan, karena apabilah desain visual menarik dan kualitas kemasan juga bagus akan menarik minat beli konsumen dan akan membuat konsumen 
membeli produk baik dengan ukuran kecil atau besar dan meskipun adanya perbandingan atau penambahan harga.

\section{REFERENSI}

Anjelia, T.R.G. (2008), Pengaruh Desain Visual Kemasan Produk Makanan UKM Kacang Paris Terhadap Minat Beli Konsumen, Skripsi Fakultas Ilmu Komunikasi, Universitas Mercu Buana, Jakarta.

Mohammad, M.B. (2012), Analisis Pengaruh Kualitas Produk, Kesesuaian Harga dan Intensitas Promosi Terhadap Keputusan Pembelian Konsumen, Skripsi Fakultas Ekonomi, Universitas Diponegoro, Semarang.

Ni, L.D. (2013), Elemen Visual Kemasan Sebagai Strategi Komunikasi Produk, Jurnal Desain Komunikasi, Vol. 6, No. 1.

Oktaviani, R. (2016), Pengaruh Kualitas Produk, Kepercayaan Merek, Dan Kepuasan Konsumen Terhadap Loyalitas Merek, Skripsi Fakultas Ekonomi, Jurusan Manajemen, Universitas Negeri Yogyakarta.
Rani, O. (2016), Pengaruh Kualitas Produk, Kepercayaan Merek, Dan Kepuasan Konsumen Terhadap Loyalitas Merek, Skripsi Fakultas Ekonomi, Jurusan Manajemen, Universitas Negeri Yogyakarta. Retno, M, Hakim, I, Salmina, M dan Arifanti, V.B. (2012), Pengembangan Pola Kemitraan Masyarakat Desa Hutan Mendukung Strategi Pembangunan Daerah Berwawasan Lingkungan, Kementerian Riset dan Teknologi, Bogor.

Rahman, A. (2008), Analisis Kepuasan Konsumen Produk Susu Ultra Milk, Skripsi Fakultas Pertanian, Program Studi Manajemen Agribisnis, IPB, Bogor.

Yamin, M. (2017), Hasil Wawancara JMHS (Jaringan Madu Hutan Sumbawa), Sumbawa Besar. 